\title{
Creativity: A Driver and Enabler of Social CoHesion
}

Creatividad: motor y potenciadora de cohesión social

\section{Teresa García Alcaraz Universitat Politècnica de Catalunya}

\begin{abstract}
Caracas, a city that has been shaped by decades of spatial, social and political division, struggles daily to overcome its complex legacy. Despite government attempts to combat these severe disparities among the population, urban form combined with constrained social imaginations have resulted in the routine replication and deepening of division in the city.

Leaving behind the urban dichotomies normally used to describe contemporary cities, which further exacerbate the idea of difference, 'in-between spaces' are identified as areas of encounter among 'strangers', capable of engendering new relationships and building citizenship.

Creativity, in all its senses, is seen as an excellent mechanism for transforming and reshaping the urban and social fabric in these 'in-between spaces', revealing multiple languages that are responsible for generating a change of paradigm in the cities of tomorrow.
\end{abstract}

KeYWORDS: Caracas, creativity, socio-spatial segregation, in-between space.

RESUMEN: Caracas, una ciudad que por décadas has sido tallada por una división espacial, social y política, lucha diariamente por superar su legado tan complejo. A pesar de los varios intentos del gobierno para combatir esta grave disparidad entre la población, la combinación de la forma urbana y el imaginario social impuesto han resultado en una repetición y profundización de la división en la ciudad.

Dejando atrás las dicotomías urbanas con las que normalmente se describen las ciudades contemporáneas, que no hacen más que exacerbar la idea de 
diferencia, se identifican los "espacios intermedios" como áreas de encuentro entre "extraños", los únicos capaces de generar nuevas relaciones y construir ciudadanía.

La creatividad, en todos los sentidos, es entendida como un elemento formidable y transformador capaz de remodelar el tejido urbano y social en estos "espacios intermedios", revelando múltiples lenguajes que son responsables de generar un cambio de paradigma en las ciudades de mañana.

Palabras clave: Caracas, creatividad, segregación socio-espacial, espacio intermedio.

RESUM: Caracas, una ciutat que per dècades ha estat tallada per una divisió espacial, social i política, lluita diàriament per superar el seu llegat tan complex. Tot $\mathrm{i}$ els diversos intents del govern per combatre aquesta greu disparitat entre la població, la combinació de la forma urbana i l' imposat imaginari social han resultat en una repetició i aprofundiment d' aquesta divisió existent de la ciutat.

Deixant enrere les dicotomies urbanes en les que normalment es descriuen les ciutats contemporànies, que no fan més que exacerbar la idea de diferència, s'identifiquen els "espais intermedis" com a punts d' encontre entre "estranys", els únics espais capaços de generar noves relacions i construir ciutadania.

La creativitat, en tots els sentits, és entesa com un element formidable i transformador capaç de remodelar el teixit urbà i social en aquests "espais intermedis", revelant múltiples llenguatges que són responsables de generar un canvi de paradigma en les ciutats de demà.

Paraules clau: Caracas, creativitat, segregació socio-espacial, espai intermedi. 


\section{Introduction}

In a recent article titled 'Towards a new epistemology of the urban?', Brenner and Schmid (2015) state that the concept of what we call 'city' needs to be reworked to embrace and understand the new changes and dynamics that affect urban agglomerations.

In analysing the above idea, this paper incorporates critical views on the city of Caracas, presented as a privileged scenario from where to understand the mechanisms that produce urban inequalities in contemporary cities.

The Venezuelan capital was forced to expand the colonial grid out from its historical centre as new settlements -slum areas, housing for the lower-middle classes, country houses for the elites, among others- began to spring up on the outskirts of its traditional city limits. This uneven growth followed the disparity of urban fabrics and forms, the unequal sprawl and the extension of the city, an indication of the fragmentation of the territory that allows academics and urban practitioners to define the city as contrasting poles: "the notions of formality and informality were appropriated by architects in order to describe squatter settlements developing around Latin American cities" (Hernández et al., 2010, p. 16).

But this study moves beyond the urban dichotomies by which contemporary cities are understood -and which inherently imply division- to recognise the importance of the interstitial spaces located where two or more types of urban fabric converge, nurturing the discourse with other terms that denote cohesion and articulation among city areas.

The notion of Zwischenstadt or "in-between city" (Sieverts, 2003) has been coined to define the socio-spatial landscape of what is called 'in-between space', and that includes the part of the city that is perceived as not quite traditional city and not quite traditional suburb (ibid).

Sassen $(1994,2001,2006)$ understands the intersection between these realities as a terrain of discontinuity in which 'something' can be created from a cultural, social and economic point of view. Similarly, Jáuregui (in Hernández et al., 2010) refers to this intersection as a 'space of flux', one that can link different parts of the city through a 'connective' function of social spaces. Hence, what is needed is an intra-local look at urban disparity in the 
fringe areas of cities where heterogenic communities live, which implies a change of paradigm in the architectures and processes involved in building an inclusive city.

According to Csikszentmihalyi (1996) creativity is "any act, idea, or product that changes an existing domain, or that transforms an existing domain into a new one" (p. 27). Although creativity remains a fuzzy concept (Kunzmann, 2012), it is undoubtedly based on multi-dimensional thinking; it requires a visionary power, and the fact that it has a positive meaning in society helps promote creative action.

In this article, therefore, the 'Tiuna el Fuerte Cultural Park', located in an in-between space in the parish of El Valle, is presented as an exploratory case study of 'engaged urbanism' (Campkin and Duijzings, 2016), which is defined as "[taking] place outside of traditional academic environments, featuring strong collaborations between academics, professional groups, community-based organisations, artists, activists and others" (2016, p. 4). In this case, creativity is understood as a powerful tool capable of going beyond existing urban dualisms, where urban interventions are seen as catalytic actions that can politicise daily activities, connect local processes to larger ones, and become the key factor in initiating urban cohesion.

Applying this new engaged urbanism to the in-between spaces of the city will serve as a means to articulate the space and promote a tool for mediation and awareness. These spaces, in time, become powerful political, social and urban mechanisms capable of developing a wide spectrum of choices that enhance coexistence.

\section{Heterotopia and in-between spaces}

In French, 'espace' has a wider application than 'space', referring to many areas designated for specific purposes or activities. Augé (2008, p. 83) describes the particular 'plasticity' of the usage of space and place, as there are complex and subtle differences.

Space (espace) is more abstract than place (lieu): space can refer to an area, a distance and, significantly in relation to Foucault's concept of heter- 
otopia, a period of time, whereas place is relational, concerned with identity and linked to an event or a story, whether mythical or real (2008, pp. 81-84). Agnew (2005) differentiates these terms, stating that space is traditionally seen as a general and objective notion, related to some form of location, whereas place refers to the particular, related to the 'occupation' of a location (2005: 142). However, Foucault (1986) favours the word 'emplacement', a term which has a sense of both space and place.

In his study of space and its historical progression through Western culture, Foucault (ibid) tells us that "the space of emplacement" was postulated in the Middle Ages, consisting of "a hierarchic and structured ensemble of places" (1986, p. 1), whereas at the beginning of modernity, he envisioned an infinitely open space, "a thing's place was no longer anything but a point in its movement" (1986, pp. 1-2). In this sense, space was seen as a homogeneous field, where extension was substituted by localisation. In recent times space is "defined by relations of proximity between points or elements" (1986, p. 2), in which "space takes for us the form of relations among sites" (ibid), what Muntañola (1998) defines as a dialogic relationship between real space and mental space.

There has been a shift from a space of binary oppositions - the open and closed, public and private, sacred and profane- and according to Foucault, the dialectical interrelation of spaces has been eroded.

Foucault (1967) adopted the concept of site to introduce a new spatial type, "heterotopia" (hétérotopie), with etymological links to another term, "utopia", which is a theoretical counterpart to heterotopia. Whereas utopias are unreal perfect spaces, heterotopias are defined as "counter-sites", simultaneously representing, contesting and inverting all other conventional sites.

Heterotopias are "other spaces", sites that represent incompatible spaces and reveal paradoxes, places such as prisons, rest homes and psychiatric hospitals that people may inhabit at particular times or because they are considered deviant. Foucault used the example of a mirror as a metaphor to describe utopia and heterotopia and clarify the duality between the reality and the unreality of utopian projects: when we look in a mirror, the image we see reflected there does not exist, but it is a heterotopia because the mirror is a real object that shapes the way we are related to our own image. 
Placing this metaphor in an urban context, the fragmentation of urban space in Caracas is (morphologically) evidenced in the differences among the four urban fabrics ${ }^{1}$ that make up the city. The meeting of two urban fabrics translates into a spatial rupture because several logics of spatial organisation converge and overlap. This convergence occurs in tension due to the apparent incompatibility of their components. It is the spatial rupture, therefore, that generates an in-between space when it is configured in the middle of two different temporal and spatial units. This confluence defines a new reality on the fringe, revealing an indisputable interstitial situation (Herrera Napoleón, 2006).

In-between spaces offer an unambiguous representation of heterotopia in the Foucauldian sense because they function as counter-sites in which spatial concepts of borders are not only mirrored but simultaneously challenged. As Foucault explains, "heterotopias always presuppose a system of opening and closing that both isolates them and makes them penetrable" (Foucault, 1986, p. 5).

In contemporary cities, in-between spaces have been referred to as badlands (Doron, 2007), no man's land (Leech, 2013), wastelands (Can, 2012), space left over after planning (SLOAP), dead spaces and border vacuums (Jacobs, 1992), terrain vague (Solá Morales, 1995). All are terms that address the "nameless spaces" that have appeared right in the heart of cities.

In his book Territorios, Solá Morales (1995) introduces the French term "terrain vague" to refer to this form of absence in the contemporary metropolis, describing obsolete, unproductive spaces, abandoned areas and buildings often undefined and without specific limits. In contrast to the idea that all in-between spaces in cities are unproductive or abandoned places, in this article I argue, in line with Solá Morales, that they need to be "reincorporated" into the productive logic of the city by transforming them into reconstructed spaces. These in-between spaces might become areas in which transformation

1. To establish a firm understanding of the urban fabrics of Caracas, this paper defines and adapts the four urban typologies identified by MARCANO, F. 1994. Cascos Urbanos: Espacio de reflexión. Los cascos de Chacao, Baruta y El Hatillo. Urbana, 1415, 121-134.: 1. old quarter areas, 2. growth-by-expansion areas, 3. empty voids and 4. areas of uncontrolled development. 
processes occur, and often result in hybrid manifestations of identity and culture from their contrasting adjacent parts. A closer look at the contemporary metropolis is needed to unfold this process of differentiation, together with "a quest for information that is often not quantifiable, sometimes escaping the systems of the logic used to analyse traditional urbanism" (García Alcaraz, 2016).

According to Solá Morales (1995), "creative practitioners" (Higgins and Morgan, 2000) address the terrain vague differently: photographers, for instance, understand these spaces as places imbued with some intrinsic value, whereas architects approach them as "problems to be solved through design" (Solá Morales, 1995).

In this article, instead of looking at these spaces as problems, I attempt to see them as solutions to urban problems.

\section{Otherness}

According to the Habitat3 Alternativo Manifesto'2, in the section 'From exclusion to citizenship: conquering the territory and being government' ${ }^{3}$, people become citizens by building their cities. In many metropolises around the world, the social production of housing, its surroundings and basic services is carried out by its inhabitants; people build their cities from earth, they inhabit city centres, build up the social fabric, and demand the right to the city that belongs not just to some, but to all.

The parish of El Valle, in the south of the Venezuelan capital, is presented as a case of what is described in this manifesto to show the perpetual problems facing most of the city's barrios, ${ }^{4}$ where aside from high rates of social exclusion, violence, unemployment and job insecurity (a large number of its

2. http://www.fiurb.org/manifiesto-de-quito-foro-h3-alternativo/

3. Author's own translation of "De la marginación a la ciudadanía: conquistar el territorio y ser gobierno".

4. "Barrio: slum or shantytown. In Venezuela, the world barrio is synonymous with the Brazilian term favela.” Martínez, C., Fox, M. \& Farrell, J. 2010. Venezuela Speaks!: Voices from the Grassroots. 
residents work in the informal sector), basic services such as clean water, electricity, garbage collection or water drainage are lacking.

Meanwhile, on the level parts of the parish, following the course of the Avenida Intercomunal de El Valle and the Valle-Coche highway-one of the main arteries into Caracas from the south- large residential towers (or gated condominiums) make up the urban landscape of the neighbourhood. These apartment blocks were built during the 1950s as a solution to the 'self-construction problem' but were insufficient to absorb the high levels of migrants arriving into the area.

Although the government implemented specific urban plans, its main focus was to develop the area by promoting highways, avenues and new residential developments for the middle-classes, which has led to a shortage of public facilities and open public spaces. Moreover, the continuously unsuccessful attempts by government institutions, professionals and the media to improve low-income areas, together with their underestimation of what the poor have to offer, have also worsened urban conditions, which have an increased disproportionately negative effect on the barrio and its residents.

The map of the Venezuelan capital reflects contrasted typologies and urban forms that provide clear evidence of the socio-spatial segregation in the city where urban fabrics are juxtaposed; this juxtaposition represents urban failure and heightens the separation between residents.

In El Valle neighbourhood, this juxtaposition reveals an in-between space on the fringe of the two areas (image 1).
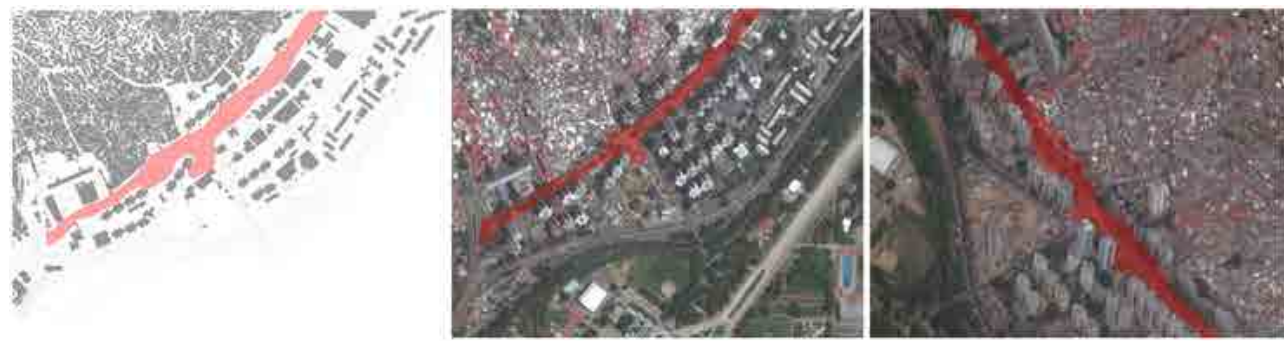

Image 1. Fringe area in the neighbourhood of EI Valle, adjoining growth-by-expansion areas and uncontrolled development areas. Source: the author. 
According to Tonkiss (2005), the making of borders creates "zones of inclusion at the same time as it draws lines of social division and exclusion" (p. 58).

In Venezuela, lines of division are often understood in terms of economic status, political beliefs and cultural diversity. Residents of adjacent communities -neighbours- are strangers to each other, not in the sense of 'unknown' but as 'not belonging'. This framing occurs by representing the barrio solely through the lens of crimes perpetrated by 'recognised strangers' and by representing prestigious communities and their conspicuous opulence through the lens of class consciousness. In this context, who is excluded and who is included? No-one and everyone.

However, a line of inclusion is redrawn in the in-between spaces during religious festivities, and political, cultural and social demonstrations and activities, which normally take place in the public space (image 2). The space surrounding these two different realities represents a shift marking the possibility of encounter with 'strangers', expressions of achievement and common aspiration, formation of civic culture, and significant spaces for political deliberation and struggle.

During these creative events, the sociological and spatial boundaries of certain spaces are diffused.

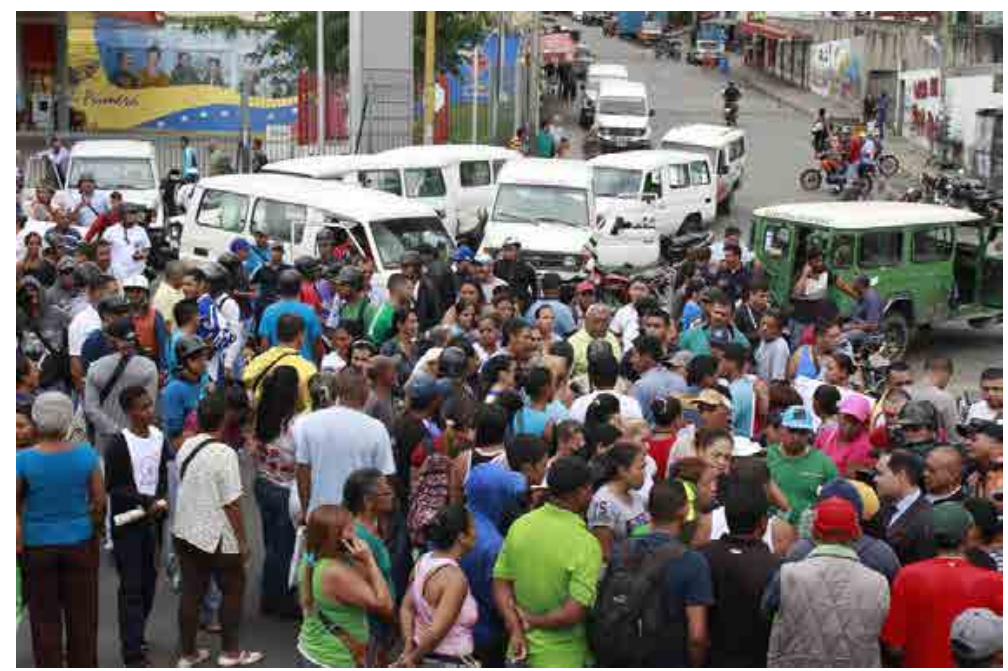

Image 2. Protestors against police abuse in Avenida Intercomunal de El Valle. Source: El Universal. 


\section{Togetherness}

According to the above reasoning, the Avenida Intercomunal de El Valle is a clear dividing line; however, from the ground, the avenue becomes both a space of opportunity for those living on the hillside and a space of necessity for the residents of the towers. Sometimes, what is generally considered a fracture or a boundary between residents actually becomes a vital space where city life is nurtured.

Tiuna el Fuerte Cultural Park, which looks onto the barrios of La Ceibita, Cerro Grande and Zamora as well as the residential complexes of Girasol, Misión Vivienda and Longaray, opened its doors in 2005 in a vacant lot, previously used as a parking space, next to Avenida Intercomunal de El Valle. The national government lent the lot to a group of young residents who wanted a cultural space in the neighbourhood, with the idea of offering a wide range of activities for children and young people. Although most of the activities taking place in this space subsequently became political, this paper only focuses on the role the space plays in the city.

According to Stohr and Sinclair (2012), "the self-described "public art activists' of Tiuna el Fuerte provide youth ages 3 to 18 with an alternative to violence by encouraging personal development and expression through graffiti, street art, poetry, video and radio production, circus arts, dance, music, and theatre". In an interview in 2010 with Miqueas Figueroa, a founding member of the space, he explained: "We felt we had a lot of reasons (social and political) to improve the area. The youth are the essence of the community and the ones who have to carry on with the revolution". 5

While members of Tiuna el Fuerte Cultural Park firmly assure that the space is not linked to any ideology and is "a space open to all", this heterotopic site has always presented certain incongruences. Conversations with some of its founding members revealed some curious - mainly political- exclusions that were hidden in the space. Its members assured that "preference is given in the space to those excluded from the formal discourse of the city", which in a sense seems contradictory because their discourse has been reversed. Who

5. Extract from an interview held in Tiuna el Fuerte, May 2010. 
is actually supporting those in power that control the formal discourse of the city? Is it necessary to continue enacting preferential rules to regulate access to public spaces?

The architecture of the site is clearly a reflection of its immediate surroundings, a mixture of permanent and temporary structures. Shipping containers have been transformed to accommodate classrooms, toilets, food markets, offices and even a theatre, reflecting all community needs (images 3 and 4). The park is a hybridisation of materiality, adaptive forms and temporary uses that together contribute to the success of the space because residents from the barrios and nearby condominiums share a common area, where they feel identified and represented.

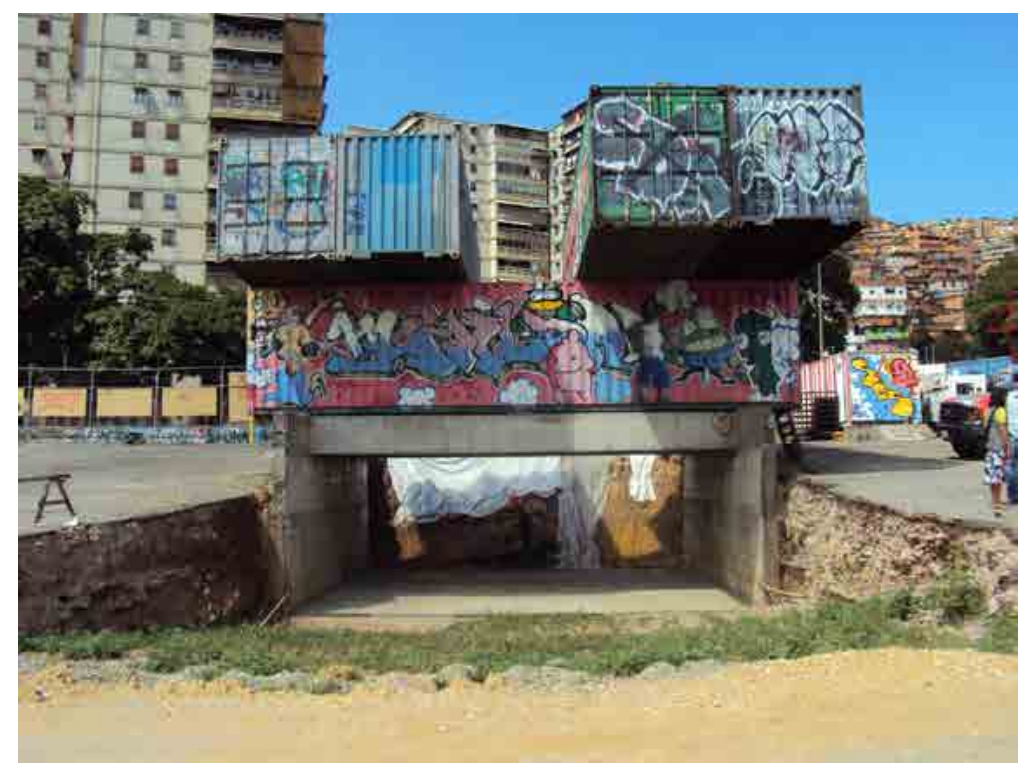

Image 3. Tiuna el Fuerte Cultural Park. Amphitheatre in progress, December 2009. Source: the author. 


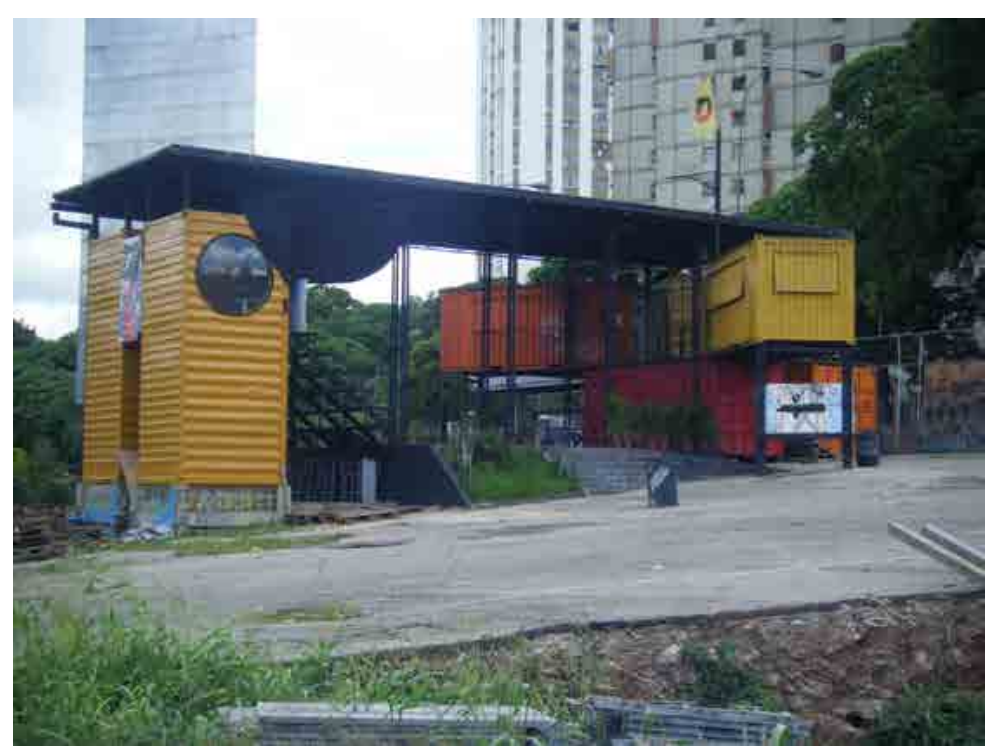

Image 4. Tiuna el Fuerte Cultural Park. Main area in May 2010. Source: the author.

Tiuna el Fuerte Cultural Park matches the aesthetic and symbolic references of the young, as most of the containers are painted with graffiti and vibrant colours; the park's symbol is also a feather representing the native chief 'Tiuna', a warrior from the Caracas tribe. National and international street artists have been invited to paint the containers with their designs, which in turn has encouraged the young people to paint and be creative.

Although the park is managed by a regular team of fifteen people, the space was conceived and built by a multidisciplinary group of professionals with the help of volunteers. After its completion, neighbours have continued to look after the space because they feel it belongs to them: "this space belongs to the community [...] We built this space by taking and transforming what capitalism throws out, from recycled materials now used in the recording room, trucks, old tyres..."6

This cultural park in El Valle could be explained according to Lefebvre's triad spatial model (Lefebvre, 1991): representational space overlays physical space, making symbolic use of its objects (1991, p. 39); this is the space of inhabitants and users that the imagination seeks to change and appropri-

6. Quote from Albert, one of the young users of the space, on a visit to the site in 2010. 
ate. Representations of space have a substantial role and specific influence in the production of space (1991, p. 42); Lefebvre understands this type of space as that conceived by engineers, architects, cartographers and urbanists through maps, designs and drawings, namely, a system of signs and codes used to organise and direct spatial relations. The final third of Lefebvre's triad is a society's spatial practice, revealed through the physical and experiential deciphering of space (1991, p. 38). This is illustrated by the large number of residents, children and young people who enter the space every day for a range of activities, from music lessons, recording a song, practising hip-hop, attending meetings, workshops, etc. The park has become part of their daily lives.

From the inside, the park is perceived as an extension of the street, its aesthetics blending it into the urban landscape, while the activities in the space match the interests and needs of local residents. Weekly activities in the cultural park include design and music workshops, dance sessions and yoga lessons, and are all organised by individuals and young entrepreneurs who want to teach others forms of expression (image 5). Occasionally, music festivals and food markets are also hosted in order to welcome as many residents as possible. From the outside, the park is neither residual nor permanent, and its appeal lies in this ambiguity of meaning.

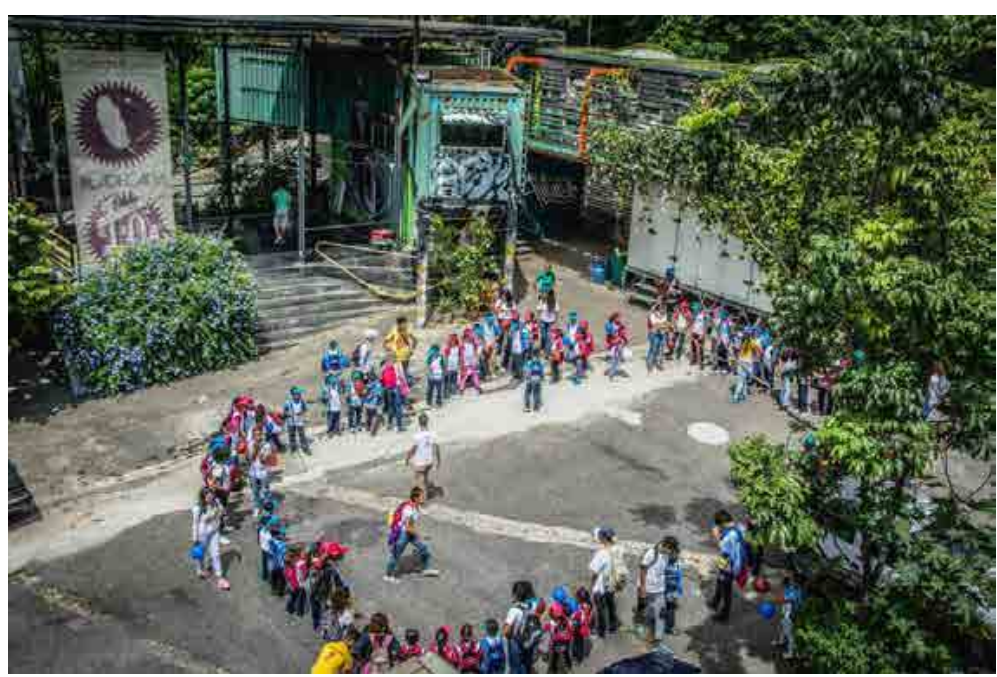

Image 5. Tiuna el Fuerte cultural park, main area in 2016. Source: Tiuna el Fuerte. 
The site has moved forward in many ways (architectonically, socially, culturally, among others) and nowadays is recognised at multi-scalar levels (micro, meso, macro), in part because of the national and international architectural awards it has won. Overall, it has had a positive impact locally as before it opened the existence of a cultural facility in the area was merely notional and since then, the perception of social polarisation has been less severe.

The key factor in the success of this space is its continuous development and constant dynamism to improve, experiment and host new activities. Nurtured by its unceasing creativity and production, the space is open to innovation, and this is the reason it has become a meeting point where culture, arts, creativity, (and politics) are all that matter.

\section{Openness. Final reflections}

This research is part of an ongoing $\mathrm{PhD}$ study conducted in different stages. After analysing several interventions in the in-between spaces of Caracas, this specific case in the parish of El Valle is the result of somewhat exceptional circumstances: an award-winning firm commissioned by the government, winning entries in national and international design competitions, continued funding while the country is in crisis... these conditions would be hard to replicate in Caracas today.

Such interventions in the urban space can be understood as a confluence of an 'architectural design' and the 'political project', the impact of which is therefore twofold: it can either generate a built environment of objects that may be understood to possess political agency, or it can be considered as a manifestation of activism in a broad sense, whether or not practice adopts a political cause as its primary objective. However, this case study places a premium on social response and the dissemination of good practice, both of which serve as an inspiration and a benchmark for real life programmes that have to be implemented on tight budgets. 
This intervention in El Valle not only entailed aesthetic changes to the city's urban landscape, but also empowered 'others' to participate in the process of building a better city for all. As stated in the Habitat 3 Alternativo Manifesto, "people became citizens by building their own cities", and the case of Tiuna el Fuerte serves as an example of social cohesion among strangers who became users of a shared space.

This cultural park generates new routines for children and young people, enabling them to escape from the structured daily dynamics of home to school and back again, and provides residents with new discoveries and opportunities by creating networks of people who share similar affinities and interests. The park has become a meeting point for the local community, a space where creativity is reinforced to escape from violence and drugs. This is key to generating new readings and discourses of the city, as creative practices might help eliminate the prejudices that exist in such unequal environments.

Tiuna el Fuerte Cultural Park set out not to confirm what already existed, but rather to make visible what was invisible, forming new possibilities of interaction between the symbolic, the imaginary and the real.

Outcomes on the ground raise important questions about the expectations of making in-between spaces 'realistic open sites' where everybody -regardless of race, gender, political views or social status- is welcome and not secretly excluded. In-between spaces should be 'open' to debate, innovate and experiment with society on all fronts, to increase society's openness to 'the stranger', to break down stereotypes and prejudices, to implement more inclusive projections towards other areas of the city -not just the barrios-, and most importantly, to ensure that arts and culture are a mode of expression that must be dissociated from any political party or figure.

In-between spaces can be associated with the Möbius strip concept (Boano and Martén, 2013) as they clearly mark the physical limit of one area and the beginning of another, but at the same time they solidify an otherwise fluid barrier, which is actually its strongest characteristic. And it is precisely in

7. Author's own translation of: «Los ciudadanos se hicieron ciudadanos haciendo ciudad». 
these transitory areas where social cohesion is possible, where the city can be envisioned as a continuum of different realities and creative practices offering opportunities to experiment with hybridisation.

\section{References}

AGNEw, J. (2005). «Space: Place». In: Johnston, P. C. A. R. (ed.), Spaces of Geographical Thought. London: Sage.

Augé, M. (2008). Los no lugares. Espacios del anonimato. Una antropología de la sobremodernidad. Barcelona: Gedisa editorial.

BoAno, C. \& Martén, R. (2013). «Agamben's urbanism of exception: Jerusalem's border mechanics and biopolitical strongholds». Cities, 34, 6-17.

Brenner, N. \& SChmid, C. (2015). «Towards a new epistemology of the urban?». City, 19, 151-182.

Campkin, B. \& DuiJzings, G. (2016). Engaged urbanism: cities and methodologies.

CAN, I. (2012). In-between space and social interaction: a case study of three neighbourhoods in Izmir. $\mathrm{PhD}$, The University of Nottingham.

Csikszentminalyi, M. (1996). Creativity: Flow and the psychology of discovery and invention, New York: Harper Collins Publishers.

Doron, G. M. (2007). «Badlands, blank space, border vacuums, brown fields, conceptual Nevada, Dead Zones». Field: A free journal for architecture, $1,14$.

Foucault, M. (1967). «Of Other Spaces, Heterotopias». Architecture/Mouvement/Continuité, 46-49.

Foucault, M. (1986). «Of other Spaces». Diacritics, 16, 22-27.

García Alcaraz, T. (2016). «Nuevas alternativas urbanas: Los movimientos sociales y sus prácticas socio-espaciales y visuales». International Conference Contested Cities. Madrid.

Hernández, F., Kellet, P. \& Allen, L. K. (2010). Rethinking the informal city: critical perspectives from Latin America. New York: Berghahn Books.

Herrera Napoleón, C. (2006). «Híbridos Urbanos: Una nueva mirada para intervenir a Caracas». Urbana, 39, 85-103. 
Higgins, M. \& Morgan, J. (2000). «The Role of Creativity in Planning: The 'Creative Practitioner'». Planning Practice \& Research, 15, 117127.

JACOBS, J. (1992). The Death and Life of Great American Cities.

Kunzmann, K. (2012). Creativity in Planning: a Fuzzy Concept?

LEECH, O. (2013). Hidden rules: are there rules and regulations even in informal settlements? Architecture Master Thesis, Bartlett School of Architecture.

LeFEBVRe, H. (1991). The production of space. Malden, MA; Oxford, Blackwell.

Marcano, F. (1994). «Cascos Urbanos: Espacio de reflexión. Los cascos de Chacao, Baruta y El Hatillo». Urbana, 14-15, 121-134.

Martínez, C., Fox, M. \& Farrell, J. (2010). Venezuela Speaks!: Voices from the Grassroots.

Muntañola, J. (1998). Transcripciones arquitectónicas 1: Texto y contexto. Barcelona: Edicions UPC, Universitat Politècnica de Catalunya.

SAssen, S. (1994). "The Informal Economy: Between New Developments and Old Regulations». The Yale Law Journal, 103, 2289-2304.

SAssen, S. (2001). «The City: Between Topographic Representation and Spatialized Power Projects». Art Journal, 60.

SAssen, S. (2006). Territory, authority, rights: From medieval to global assemblages. Princeton: Princeton university press.

SiEverTs, T. (2003). Cities without cities: an interpretation of the Zwischenstadt. London, New York: Spon Press.

Solá Morales, I. D. (1995). Territorios. Barcelona: Gustavo Gili.

Stohr, K. \& Sinclair, C. (2012). Design Like You Give a Damn 2.

Tonkiss, F. (2005). Space, the city and social theory : social relations and urban forms. Cambridge: Polity. 
